This is a self-archived version of an original article. This version may differ from the original in pagination and typographic details.

Author(s): Lakkala, Keijo

Title: Disruptive Utopianism : Opening the Present

Year: 2020

Version: Accepted version (Final draft)

Copyright: (c) Author \& Zed Books, 2020

Rights: In Copyright

Rights url: http://rightsstatements.org/page/lnC/1.0/?language=en

Please cite the original version:

Lakkala, K. (2020). Disruptive Utopianism : Opening the Present. In T. Eskelinen (Ed.), The Revival of Political Imagination : Utopia as Methodology (pp. 20-36). Zed Books.

https://doi.org/10.5040/9781350225633.ch.002 


\section{Disruptive Utopianism: Opening the Present}

\section{Keijo Lakkala}

Having noted the multiple meanings of utopia and its multiple functions in facilitating social criticism, this chapter turns to broadening the discussion through the notion of utopias as a form of social practice. Specifically, utopia can be understood as a social counter-practice motivated by a desire for better being. Utopia has the potential to both relativise the current society (to distance us from the existing and given social order) and to create cracks within the present and open possibilities for new forms of being and doing. Disruption of the present opens a plurality of futures. The latter kind of utopianism (disruptive utopianism) is developed in this chapter with the concept of 'the crack', as theorised by John Holloway (2010). As will be shown, Holloway's theorizations provide a useful theoretical starting point for developing the notion of 'utopian counter-logical practice'.

I will discuss functions of utopia by moving from counter-images to counter-practices, and showing their connections. Understanding utopias as counter-images of the present means understanding them as relational, dynamic and open, as opposed to absolute, static and closed. Yet the function of utopias can be developed further, as 'lived utopianism' (Sargisson \& Sargent 2017) consisting of counter-practices. In this interpretation, utopias are not just theoretically constructed counter-images of the present but formulations of alternative logics of social, economic and political practices. As relational and disruptive counter-practices, utopias open up the future by creating cracks on the social cohesion of the present.

\section{Utopia as Critical Counter-Image of the Present}

In the Introduction, different functions of utopias were discussed. The functional approach to utopias asks: What are utopias for? This question has attracted various kinds of answers. (Levitas 2010): Critical and facilitating. Even within relatively coherent theoretical approaches, utopias have been seen as having both negative and positive functions. For instance within 
Marxism, utopias have been interpreted through the negative function of preventing social change and the positive function of facilitating such change (Levitas 2010,6 ). This was noted in the introduction by reference to $19^{\text {th }}$ century utopian socialists as unable to facilitate social change in Marx and Engels' (2004) eyes. The same kind of approach later made Lenin critical towards utopias in general, as he wrote in 1912: 'In politics utopia is a wish that can never come true - neither now nor afterwards, a wish that is not based on social forces and is not supported by the growth and development of political class forces' (Lenin 2004). For Lenin, utopias are mere day-dreams, fantasies and inventions that can only express the historical situation, but they cannot work politically.

The function of preventing social change is a feature which can be found mainly in the abstract and static forms of utopian thought. The negative function of utopian thought can also sometimes be understood as compensatory. This is what was also described in the Introduction by reference to Lewis Mumford's $(1922,20)$ concept of 'utopias of escape'. Mumford's preference, 'utopia of reconstruction', recognizes the hazards and evils of the present society to human beings and aims to reconstruct a society more suitable for human beings. 'The utopia of reconstruction is what its name implies: a vision of a reconstituted environment which is better adapted to the nature and aims of the human beings who dwell within it than the actual one; and not merely better adapted to their actual nature, but better fitted to their possible developments' (Mumford 1922, 21). The utopia of escape leads back to the ego of the utopian thinker, but the utopia of reconstruction orientates towards the outside world and aims to change it.

In addition to being (more or less) facilitating, utopias always serve the function of critique (Levitas 2010, 208). Constructing a utopia is in itself implicitly critical towards the present and expresses the need for social change. Why would anyone construct utopias, if there was nothing to improve in the existing society? Utopias force a comparison of the existing society with an imaginary society, creating a contrast effect which illuminates the existing injustices. Just as Manuel \& Manuel $(1979,446)$ write, building utopia as an antithesis to reality, a kind of 
counterpoint, is one of the oldest devices in utopia-writer's repertory. This contrast is already visible in Thomas More's Utopia (1516).

It has sometimes been said that utopias 'relativise' the present (e.g. Bauman 1976, 13), meaning that the present is always only a moment in an open-ended historical process. This has two implications: 1) the present can always be imagined to be different, and 2) the present does not determine the future, but can lead to a number of different futures depending on choices made in the present. Utopias are then tools for extrapolating the possibilities of the present. Utopias do not transcend the current reality, but draw from the experience and the cravings of their own time. The utopian ideals of an era are born from the double pressure of the real needs of that era's generation and the stubborn historical realities found in their time.

By creating a counter-image, utopias are the negation of the present. Francis and Barbara Golffing (1971) elaborate this idea in their article An Essay on Utopian Possibility: 'Each generation entertains its own image of the future, and the image is eminently historic. Even as the world has not stood still since Campanella, or Bacon, or William Morris wrote, so neither has that counterworld - no-world, no-place (Utopos) - stood still which forms its inevitable complement. Any yes-world requires a no-world to balance it.' (Golffing \& Golffing 1971, 3435).

As critical counter-images, utopias are always 'yes-worlds', in addition to being 'no-worlds'. 'Yes-world' refers here to a positive depiction of a world we desire. 'No-world', on the other hand refers to the world we want to leave behind, the troublesome present the 'yes-world' aims to overcome. A utopia is then not only a critical counter-image for highlighting the problems of its own time, but also a historical and a political goal. Utopia can be understood as a political philosophy that investigates, compares and analyses ends, means and existing historical conditions, in order to encourage transformative action. A concern with the ends of action can be found in several imagined societies. Utopian philosophy does not just construct alternative principles for our society, but also tries to imagine what society would be like, if utopias were put into practice. When exploring these principles, utopian philosophy also 
questions the principles that organise existing institutions. This task of utopian philosophy has been well articulated by Peter G. Stillman:

'The utopian societies (what is not) serve as new perspectives from which to investigate the ideals, undertakings, and institutions of contemporary society, encourage a critical perspective on them, inspire a thoughtful evaluation of present and alternative individual and social ideals and activities, and consider if and where change is feasible and desirable.' (Stillman 2001, 11.)

\section{Dynamic utopias}

Utopian philosophy thereby fosters critical thinking about the existing conditions of current society and encourages envisioning alternative ways of living. It crystallises the core problems of the present and makes us ask questions regarding the collective goals of the current society. Are they worth pursuing or could some other goals be more important? The purpose of utopian philosophy is not to create static blueprints for a new society but to create critical counterimages of a society in which radically new and better principles are put into practice. The role of utopias as counter-images of the current society makes them historically conditioned and relational.

Following philosopher and literary critic Darko Suvin, utopias can be divided into two kinds: Open and closed utopias. Suvin sees no theoretical (nor empirical) grounds to see utopias as always closed and static. And even if all utopian texts would have historically been static and closed, it does not follow that this would necessarily be the case in the future too. The concept of utopia is not so much ontological than it is epistemological. Utopia is a thought experiment. Especially literary utopias are heuristic tools for envisioning a better world. (Suvin 1997, 126128.)

The concepts of open and closed (dynamic and static) utopia can be elaborated by making a distinction between utopias focused on locus and those focused on utopian horizon. Utopian 
locus refers to the historical situation which shapes the utopian vision. Utopian horizon, on the other hand, means the vision in itself. The utopian horizon is dependent on the utopian locus and its historical development and therefore the utopian vision will be different in every historical situation. This distinction can be further developed as analysis of three necessary elements for utopian thought: (a) the place of the agent who is moving, their locus; (b) the horizon toward which the agent is moving; and (c) the orientation, a vector that conjoins locus and horizon. What is essential for the horizon is that it keeps changing as the agent moves through different loci.

Orientation, on the other hand, can remain more or less stable even when the space where the agent moves changes. This is why it can conjoin locus and horizon together. In utopian texts, the orientation of the agent is always towards a better mode of being. In utopian texts, orientation towards a better mode of being is expressed by creating possible analogical worlds to the empirical world, counter-images of the present. (Suvin 1997, 130-133).

Utopia as a method for creating counter-images is always dynamic because the counter-images are always grounded in their particular historical locus, which they reflect negatively. The same is true also for the facilitating function of utopias. When utopias facilitate social change they do not try to create the best of all possible worlds, but to transcend the current society. In both functions, utopias are grounded in the historical situation and thereby necessarily in relation to their own time. They are not absolute goals for mankind but historical counter-images of the present. The point of utopias as counter-images is not to express ideas of perfection and absolute harmony but to enable distance from the existing world and to create intellectual space for thinking alternatives.

\section{Utopian Counter-Practice: The crack}

Utopias are not, however, just counter-images. The critical distance that utopias offer to the existing society can be understood on a very concrete level of social counter-practices. Both utopian counter-images and counter-practices are expressions of utopian desire for a better 
being but they also have certain dialectics between them. Counter-images can either implicitly or explicitly inform and motivate counter-practices. All counter-practices do have at least an implicit vision of what kind world they want to create and at least an unreflected counter-image behind them that facilitates and motivates their inner logic. Often this counter-image can also take explicit, reflected and conceptually mediated forms. Counter-images can be translated into a more or less coherent set of principles, values and objectives the utopian counter-practice aims to achieve.

In this case, what needs to be observed is the inner structure and logic of these practices. Utopian qualities can be found in different communal, economic and cultural experiments, when one pays attention to the logic according to which they are carried out. These practices can be described as counter-logical social practices that clash against the logic of the present and potentially create cracks to the existing social cohesion. Utopian futures grow from these cracks.

The idea of 'the crack' is introduced by John Holloway in Crack Capitalism (2010). While Holloway mainly discusses strategies of social transformation, his ideas are useful for developing a conception of utopian practice. The usual understanding of social transformation has been spatial, and thereby social transformation has been associated with capturing or radically altering spaces, 'understood in traditional theory as states' (Holloway 2010, 236). However, Holloway argues that social transformation should be understood in 'apocalyptic terms', transforming not only space (state, town, or social center), but also time and relations within it. This for Holloway, means breaking duration, it means seeing 'each moment as distinct, as full of possibilities: The realization of these possibilities can mean driving each moment beyond its limits' (Holloway 2010, 236). The goal for revolution is to go beyond all limits, to the point of shedding the time itself and blending with eternity.

This transformation of time can be located in everyday behaviour and practices of the present. It needs to be located in the movements, rhythms and paces of bodies in the present. It needs to be located in the logic of practices here and now. Holloway's theory is, it can be argued, useful for developing a new kind of disruptive utopianism that does not dictate the outcome of 
history but aims to open up the present. Not only are there utopian qualities in Holloway's theory (such as a strong desire for a better being), but it can be used to formulate a new kind of understanding of utopia. In this new understanding, utopia is not only a counter-image of the present, but also a counter-practice of the present, motivated by a desire for better being. This counter-practice operates according to radically different logic when compared to the logic of the present. Utopian counter-practices are about unsettling the everyday, they are about disrupting the present (see Garforth 2009).

Creating a crack on the surface of the present begins with refusal. It begins with abandoning the present and creating an alternative through revolutionary praxis. Holloway (2010) writes: 'Break. We want to break. We want to break the world as it is. A world of injustice, of war, of violence, of discrimination, of Gaza and Guantanamo. A world of billionaires and a billion people who live and die in hunger. A world in which humanity is annihilating itself, massacring non-human form of life, destroying the conditions of its own existence. A world ruled by money, ruled by capital. A world of frustration, of wasted potential. We want to create a different world'. (Holloway 2010, 3).

This different world, according to Holloway, is created exactly through the 'method of the crack' (Holloway 2010, 6). The axiom of the method of the crack is that the world is always open for change, while only the ideology of the dominating class makes it seem closed and finished. The walls of the closed world are rapidly closing but the possibility for change always exists. It is only the question of revolutionary method that solves how these closing walls are to be torn down. Some revolutionaries aim to create a party lead by a revolutionary avant-garde to 'denounce the movement of the walls', while others (Holloway included) 'run to the walls and try desperately to find cracks, or faults beneath the surface, or to create cracks by banging the walls' (Holloway 2010, 6). This of course relies on the assumption that such cracks are always there. Finding, locating and opening these cracks is just a matter of practical-theoretical activity, a matter of praxis. Theory is needed for understanding the nature of the closing wall, locating the weak spots of the wall and practical activity is needed for creating and opening the cracks of the wall. (Holloway 2010, 6.) 


\section{Cracks in walls: Interstitial strategy}

Opening these cracks found on the 'walls' of the present is for Holloway 'the opening of a world that presents itself as closed' (Holloway 2010, 9). The method of the crack contains 'a dialectic of misfitting' (Holloway 2010,9). This simply means to think from the point of view of those who do not fit, who are left outside. It even encourages this misfitting. It encourages nonidentity, escaping from given identities. 'We' are not working class, 'we' do not have a nationality. Our subjectivity cannot be reduced to the categories of the present. 'We' are the non-identity, 'we' are the force that contradicts all identification, the force that overflows is subjectivity' (Holloway 2009, 14).

'We', according to Holloway $(2010,9)$ is the indefinable subject that cannot be reduced to any given identity category. 'We' is something that could be described as negative universality. This is where the 'dialectic of misfitting' comes into play. 'We' refers to the people who refuse to fit in to capitalism. 'Ever more people simply do not fit in to the system, or, if we do manage to squeeze ourselves on to capital's ever tightening Procrustean bed, we do so at the cost of leaving fragments of ourselves behind, to haunt' (Holloway 2010,9). The fragments that haven't fit to 'capital's ever tightening Procrustean bed' are the basis of the crack that could open a new world. 'We' who do not fit in are the basis of the crack. 'We want to understand the force of our misfitting, we want to know how banging our head against the wall over and over again will bring the wall crumbling down' (Holloway 2010, 9). 'We' is the subject that is not only unable, but also unwilling to fit in to the present capitalist society. It is the subject that screams 'No!'.'In the beginning was the scream' (Holloway 2003, 15). Screaming 'No!' is, according to Holloway $(2010,26)$, an act of dignity. It means that 'here and now, we refuse to subordinate our activity to the rule of capital: We can and will and are doing something else' (Holloway 2010, 26). This can be understood so that in Holloway's thought the new world is created through alternative logic of practice. 
We can make distinctions between four different kinds of ways cracks can be created on the surface of the present. The first form of crack is a territorial one. Different kinds of territories occupied under a community living according to radically different set of values can create territories in which the logic of capitalism has been overturned. Most obvious examples of these kinds of territorial cracks are the Zapatista communities in Chiapas, Mexico and the territories occupied by Kurdish militias in the Rojava region. The creation of the crack, however, cannot be thought of in terms of territory alone. Another way of thinking it is through resource and action. The action that aims for example to decommodify vitally important resources is a form of cracking capitalism, although it cannot be reduced to any specific territory. In this situation, the crack is opened through the creation of 'commons' (Holloway 2010, 29).

Another form of crack is a temporal one. One of the most famous examples of this kind of cracks are medieval festivals as described by Mikhail Bakhtin: 'On such days there is greater abundance in everything: food, dress, decorations. Festive greetings and good wishes are exchanged, although their ambivalence has faded. There are toasts, games, masquerades, laughter, pranks, and dances. The feast has no utilitarian connotation (as has daily rest and relaxation after working hours). On the contrary, the feast means liberation from all that is utilitarian, practical. It is temporary transfer to the utopian world' (Bakhtin 1984, 276). The medieval festival is a form of temporal crack since it suspends the normal, everyday flow of things and creates a temporal, alternative world. Another example of temporal crack is what Hakim Bey (2003) calls 'Temporarily Autonomous Zones', momentary spaces of insurrection which disrupts the business as usual.

Temporality can be seen as a crucial dimension of struggle. This dimension is important when cracks are created in complex spaces. The sense of community that is, according to Holloway $(2010,30)$, needed for creating an autonomous zone does not typically exist in big cities, for example. 'Certainly there are plenty of spatial cracks in the cities: Social centres, squats, community gardens, publicly enjoyed spaces, but often our communities are formed on a temporal basis' (Holloway 2010, 30). These spatial cracks are usually only temporary and after a project is finished, the organisers go their different ways. However, although these cracks are 
only temporary, their 'rage' can 'create an otherness, a different way of doing or relating' (Holloway 2010, 30). One example of this kind crack that has a strong temporal dimension was created during 2001 crisis in Argentina: 'The argentinazo of 19/20 December 2001 in the cities of Argentina was not just a spatial crack, it was also a temporal crack, a moment of rage and celebration when people descended to the streets with their pots and pans to declare that they had had enough, that all the politicians should go [...] and that there must be a radical change. $\mathrm{A}$ social energy was released, different ways of relating were created. This was a temporal crack in the patterns of domination.' (Holloway 2010, 30.)

The second example of cracks in the patterns of domination used by Holloway $(2010,31)$ is different sorts of disasters. Wars and natural disasters (earthquakes, tsunamis and hurricanes for example) do (strangely) have utopian potential, since they not only cause suffering but also 'a breakdown of social relations and the sudden emergence of quite different relation between people, relations of support and solidarity' (Holloway 2010, 31). Holloway $(2010,32)$ quotes Rebecca Solnit who suffered the consequences of Hurricane Juan in Halifax, Nova Scotia. According to Solnit, disasters such as Hurricane Juan suspend ordinary time and our roles and fates in society. The disasters cause obstacles to fall away and offer new possibilities of What one can do; who one might speak to; and, where one's life might be going. Everyday troubles and petty desires do not matter in a disaster situation. This is the hopeful side of these often horrible and devastating disasters. Disasters change our expectations about time and how things are supposed to work. 'The world is turned upside down just as surely as it is in a carnival: not just the physical but the social world as well [...] they open a window onto the possibility of another world and lay bare the miseries of the existing one' (Holloway 2010, 32).

At the moment it is, of course, the ongoing climate disaster that has, in a way, the potential to create cracks in the social cohesion of the present. Although climate change is an existential threat to humanity, it is also a force that can open the possibilities for social change. The climate crisis we are at the moment living in could create a need for new counter-images of a better, more ecologically stable society that could facilitate the masses moving towards a better future. There is, of course, a long tradition of eco-utopianism in the form of both utopian 
literature (see for example Callenbach 1990, McCutcheon 2015) and utopian practice (see for example Liftin 2014, Hong \& Vicdan 2016), but so far these kinds of utopias have not facilitated large scale social transformation.

The current situation is, however, so much worse than before that it could potentially work as a creative pressure to generate counter-images of the future. In fact, weak signs of this can be seen already. The IPCC Special Report from October 2018 - that demands 'rapid and far reaching transitions in energy, land, urban and infrastructure [...] and industrial systems' (IPCC 2018) - has already fueled new social movements such as Extinction Rebellion who demand a radical change in the current system through the usage of non-violent strategies and tactics (Extinction Rebellion 2019). They describe themselves as 'an international apolitical network using non-violent direct action to persuade governments to act on the Climate and Ecological Emergency' (Extinction Rebellion 2019). Their vision of the future, however, is hardly utopian. Their vision of change can be reduced to a one of survival. Only vague utopian demands of 'regenerative culture' are proposed (Extinction Rebellion 2019). There is nothing inherently wrong about this, indeed it might be impossible to think about the future because of the urgency of the current threats. The problems we are dealing with right now do not offer a possibility or time to think about all-encompassing alternatives.

This experience of the urgent need for change can, however, later work as a catalyst for new future oriented utopias. Even Extinction Rebellion might in time develop more detailed and concrete visions of the future through their Citizens' Assemblies which they use to find possible solutions to the current problems (Extinction Rebellion 2019). While this is a real possibility, at the moment no large-scale facilitating visions of a better world can be found in the arena of politics. And it is exactly this absence of mass-utopia why utopias and utopianism should focus mainly on the present. Utopianism in the form of utopian counter-images and in the form of utopian counter-logical practices can potentially 'expose the present', making visible different ways of thinking and different ways of being in the here-and-now. And if we can create new ways to think about the present and live in it, we can also imagine different futures. Utopian counter-logical practices can create cracks on the surface of social cohesion (and our 
experience of the society we live in) and give us the possibility to think and debate about the future again.

Counter-logical utopian social practices have the power to not only create cracks in the social cohesion of the existing society, but they also can potentially create cracks in our perception of the social world, in the way we experience and interact in the social world. Counter-logical utopian social practices can teach us to see the present society from a surprising perspective, teaching us to see the possibilities for being otherwise. These practices do not, however, need to exist in a community separated from the existing society. They can also exist within the present in the form of a lived utopia.

Counter-logical utopian social practice is about creating new forms of practices within the present. It does not need to step outside of the present, but it can also work against the present within the present itself. It is about following a radically different logic of doing in the here and now that is motivated by a desire for better being. Examples of these kinds of counter-practices can be found from the theory of P2P (peer to peer) and timebanking which both abandon the logic of profit in favor of a logic of benefit in social practices. Both of these examples express the idea of the possibility of alternative logic for the present. They do not, however, imply the idea that a new community should be created outside of the present, rather they aim to turn the logics of our social practices into new configurations.

In their Peer to Peer. The Commons Manifesto (2019) Michel Bauwens, Vasilis Kostakis and Alex Pazaitis argue for the possibility of a new social logic of value production to emerge from within the present social world (Bauwens, Kostakis \& Pazaitis 2019, 15). This new logic of value creation is based on what Bauwens, Kostakis and Pazaitis call the generative model of peer production in opposition to the extractive model of capitalism. The extractive model of capitalism relies on the logic of profit: Everything it does is aimed at maximizing profit through exploiting nature, human labour and human interaction, social cooperation. The latter form of exploitation can be seen especially well in the form of cognitive capitalism that exploits networked social cooperation through unpaid activities that can be captured and financialized by propriety 'network' platforms. Cognitive capitalism extracts the positive externalities created 
through human cooperation. For example, the logic of practice of many commercial social media platforms such as Facebook, Uber, Airbnb and Kickstarter is based on capturing the value of their members' social exchange; on gathering the data of their users interactions, and then monetizing this data for profit. Cognitive capitalism focuses on the logic of extraction in every step it takes. (Bauwens, Kostakis \& Pazaitis 2019, 37.)

The general logic of capitalism can be derived from this extractivist model of value creation: it is the logic of profit that motivates the whole capitalist social system. What Bauwens, Kostakis and Pazaitis suggest is a shift of logic from the extractivist capitalist logic to a new logic of social practice, to a new logic of production. This new logic of production can be called 'commonsbased peer production' - CBPP in short. CBPP can be seen as a counter-practice to the extractivist logic of capitalism since it does not function according to logic of profit, but rather according to logic of benefit: its priority is to produce use-values instead of exchange-values (Bauwens, Kostakis \& Pazaitis 2019, 11). 'CBPP is socially embedded and oriented towards the creation of use-value. It does not rely on individual motives to gain from barter and trade to allocate resources; sharing freely is considered virtuous' (Bauwens, Kostakis \& Pazaitis 2019, 15). CBPP can be described as a new logic of collaboration and social practice. It is a new way of collaboration between networks of people who freely organize around a common goal using shared resources. Examples of this kind of logic of practice can be found from such projects as Wikipedia and Linux which do not work according to the logic of profit, but according to the logic of benefit and use-value (Bauwens \& Kostakis 2016, 163).

According to Bauwens, Kostakis and Pazaitis, this new logic of social practice has political effects. From 'a gramscian perspective', they argue that CBPP can potentially have the power to advance alternatives to 'what is considered 'normal' and legitimate' (Bauwens, Kostakis \& Pazaitis 2019, 31). CBPP has the potential to create cracks on the social cohesion of the present and open up the possibility for a different future. It 'relativizes' the extractivist capitalist logic with a radically different logic of doing and creates a crack from which different future can arise. Even if the future CBPP society does not as a whole evolve, it still has by creating cracks 
on the surface of the social cohesion served a political function in counter-hegemonical endeavours.

A similar counter-logic of social practice can be found from the idea of time-based currency or 'timebanks'. It too organizes itself around the logic of communal benefit instead of around the logic of profit. The core idea in timebanking is that everyone's work is of equal worth. For example, one hour of babysitting is equal to one hour of providing accounting services. This essential principle of timebanking can be seen standing against the main principles and premises of the current money system and capitalist markets, which value everyone's time and work in highly unequal ways: The completely parasitic activities of a stockbroker is valued much more highly than the necessary (and, unfortunately, unpaid) labour of mothers and other caregivers. The idea of timebanking is to provide an alternative logic of social practice that helps people to meet important personal and household needs in more socially satisfying, equal ways. (Peltokoski et al. 2015.)

The logic of timebanking is here contrasted against the logic of money and the premises of the current money system and capitalist markets. Timebanking offers a radically different logic of social practice, a radically different form of economic interaction. It presents a counter-logic that has the potential to clash against the logic of the present. In 2013 this clashing happened in Finland, where tax authorities of the state came out with new taxation guidelines. These new guidelines required taxing skilled work services of timebanks according to their market value (in euro) (Peltokoski et al. 2015). The State of Finland required translating the logic of the social practice of timebanking to the logic of money and profit. The two logics were fundamentally incompatible and the new logic of social practice realized by timebanking clashed against the logic of the present.

In addition to CBPP and timebanking, there are plenty of other examples of what I consider to be utopian counter-logical social practices that clash against the present and have the possibility to create cracks on the surface of the present where a future could arise. Chris Carlsson has together with Francesca Manning presents various utopian counter-logical social practices: Vacant-lot gardeners, 'outlaw' bicycling and cash-free gift economic practices 
(Carlsson \& Manning 2010, see also Vaneigem 2012, 58-65). All of these practices can be seen as standing against the logic of the present society. It could be argued that they are all practices that live utopia in the here and now. These practices enter into a new world, into a world which is not based on abstract labour but on useful-creative doing, on a wholly new logic of doing. Utopia can be understood here as a world that already exists here and now, in the cracks, as a movement. To use more strategic language, one could describe this kind of utopianism 'interstitial' (see Wright 2010, 322-323).

\section{Conclusion}

What is here called utopian counter-logical social practice is a form of 'historical experimentalism' (see Honneth 2015, 51-75) and it bases itself on the idea that history in itself does not have an inner teleology that will eventually bring us to utopia. Instead, utopian counter-logical social practices experiment with different logics of social interaction, economical activities and political decision making. The teleological idea about historical progress eventually bringing us to utopia implies a static goal that eventually wraps itself under the crust of closed totality. However utopian counter-logical social practices do not orient themselves towards a closed future state of being, but aim constantly to keep the present dynamic open for change. For utopian counter-logical social practices, the idea of closed totality and end of history are inherently absurd and meaningless. The closure of the world and the end of history are impossible in the context of utopian counter-logical social practices. Utopianism is about openness and about offering radical alternatives, not about closure and perfection.

It is obvious, that for a large-scale social transformation historical experimentation with different logics of social practices is not enough. I am not advocating here exclusively 'folk political' small scale experimentalism (see Srnicek \& Williams 2015, 5-23). We will, eventually, need a collective, facilitating, future-oriented mass-utopia to tackle the global problems we are facing today. But in a situation where our social imagination has become privatized and our highest hopes seem to revolve around bare survival, the production of utopian counter-images 
and experimentation with counter-logical social practices have value as such. They help to distance ourselves from the present and create cracks from which the future can, eventually, grow out of. This 'opening' function is at the moment the primary function of utopianism. The closedness of the present calls for a plurality of social experimentation and utopian visions of the future. History is not teleological and there is more than one possible future ahead of us. This is where the need for utopian social imagination comes into play. In a situation where it is difficult to imagine alternatives for destructive, anthropocidal capitalism, we need to teach ourselves to dream and to imagine again. The function of utopian counter-logical social practices is to show the possibility of another world in everyday life.

\section{References}

Bakhtin, M. (1984) Rabelais and His World. Bloomington: Indiana University Press.

Bauman, Z. (1976) Socialism. The Active Utopia. London: George Allen \& Unwin Ltd.

Bauwens, M. \& Kostakis, V. (2016) 'Why Platform Co-ops Should Be Open Co-ops?' In T. Scholz \& N. Schneider (eds.) Ours to Hack and to Own. The Rise of Platform Cooperativism, a New Vision for the Future of Work and a Fairer Internet. New York/London: OR Books, pp. 163-167. Bauwens, M., Kostakis, V. \& Pazaitis, A. (2019) Peer to Peer: The Commons Manifesto. London: University of Westminster Press.

Bey, H. (2003) T.A.Z. The Temporary Autonomous Zone, Ontological Anarchy, Poetic Terrorism. New York: Autonomedia.

Callenbach, E. (1990) Ecotopia. A Novel. New York: Bantam Books.

Carlsson, C. \& Manning, F. (2010) ‘Nowtopia: Strategic Exodus?’ Antipode 42 (4), 924-953.

Extinction Rebellion. (2019) About us. https://rebellion.earth/the-truth/about-us/. 
Garforth, L. (2009) 'No Intentions? Utopian Theory After the Future'. Journal for Cultural Research 13, 5-27.

Golffing, F. \& Golffing, B. (1971) 'An Essay on Utopian Possibility'. In G. Kateb (ed.) Utopia. The Potential and Prospect of Human Condition. New York: Routledge, pp. 29-40.

Holloway, J. (2010) Crack Capitalism. London/New York: Pluto Press.

Holloway, J. (2003) 'In the Beginning was the Scream'. In W. Bonefeld (ed.) Revolutionary Writing. Common Sense Essays in the Post-Political Politics. New York: Autonomedia, pp. 15-22.

Hong, S. \& Vicdan, H. (2016) 'Re-imagining the utopian: Transformation of a sustainable lifestyle in ecovillages'. Journal of Business Research 69 (1), 120-136.

Honneth, A. (2015) The Idea of Socialism. Towards a Renewal. Cambridge: Polity Press.

IPCC (2018) Global warming of $1.5^{\circ} \mathrm{C}$. An IPCC Special Report on the impacts of global warming of $1.5^{\circ} \mathrm{C}$ above pre-industrial levels and related global greenhouse gas emission pathways, in the context of strengthening the global response to the threat of climate change, sustainable development, and efforts to eradicate poverty. Geneva: World Meteorological Organization. Lenin, V.I. (2004) 'Two Utopias'. In Lenin Collected Works. Volume 18. Marxists Internet Archive. https://www.marxists.org/archive/lenin/works/1912/oct/00.htm.

Levitas, R. (2010) The Concept of Utopia. Bern: Peter Lang.

Litfin, K.T. (2014) Ecovillages. Lessons for Sustainable Community. Cambridge: Polity Press. Manuel, F.E. \& Manuel F.P. (1979) Utopian Thought in the Western World. Oxford: Basil Blackwell.

Marx, K. \& Engels, F. (2004) Manifesto of the Communist Party. In Marx / Engels Selected Works. Volume 1. Marxists Internet Archive. https://www.marxists.org/archive/marx/works/1848/communist-manifesto/ 
McCutcheon, E. (2015) 'More's Utopia, Callenbach's Ecotopia and Biosphere 2'. Moreana 52 (201/202), 149-170.

Mumford, L. (1922) The Story of Utopias. New York: Boni \& Liveright.

Peltokoski, J., Toivakainen, N., Toivanen, T. \& van der Wekken, R. (2015) Helsinki Timebank: Currency as a

Commons. In D. Bollier \& S. Helfrich (eds.) Patterns of Commoning. Amherst: The Commons Strategies Group \& Off the Common Books.

Sargisson, L. \& Sargent, L.T. (2017) ‘Lived Utopianism: Everyday Life and Intentional Communities'. Communal Societies 37 (1), 1-24.

Srnicek, N. \& Williams, A. (2015) Inventing the Future: Postcapitalism and a World Without Work. London/New York: Verso.

Stillman, P. G. (2001) 'Nothing is, but what is not': Utopia as Practical Political Philosophy'. In B. Goodwin (ed.) The Philosophy of Utopia. London/New York: Routledge, pp. 9-24.

Suvin, D. (1997) 'Locus, Horizon, and Orientation: The Concept of Possible Worlds as a Key to Utopian Studies'. In J. O. Daniel \& T. Moylan (eds.) Not Yet: Reconsidering Ernst Bloch. London/New York: Verso, pp. 122-137.

Vaneigem, R. (2012) The Revolution of Everyday Life. Oakland: PM Press.

Wright, E.O. (2010) Envisioning Real Utopias. London/New York: Verso. 